\title{
Denitrification of a landfill leachate with high nitrate concentration in an anoxic rotating biological contactor
}

\author{
Susana Cortez $\cdot$ Pilar Teixeira $\cdot$ \\ Rosário Oliveira $\cdot$ Manuel Mota
}

Received: 24 June 2010/ Accepted: 18 November 2010/Published online: 12 December 2010

(C) Springer Science+Business Media B.V. 2010

\begin{abstract}
The denitrification performance of a labscale anoxic rotating biological contactor (RBC) using landfill leachate with high nitrate concentration was evaluated. Under a carbon to nitrogen ratio $(\mathrm{C} / \mathrm{N})$ of 2 , the reactor achieved $\mathrm{N}^{-\mathrm{NO}_{3}}{ }^{-}$removal efficiencies above $95 \%$ for concentrations up to $100 \mathrm{mg}$ $\mathrm{N}^{-\mathrm{NO}_{3}}{ }^{-} 1^{-1}$. The highest observed denitrification rate was $55 \mathrm{mg} \mathrm{N}-\mathrm{NO}_{3}{ }^{-} \mathrm{l}^{-1} \mathrm{~h}^{-1}\left(15 \mathrm{~g} \mathrm{~N}^{-N}{ }_{3}^{-} \mathrm{m}^{-2} \mathrm{~d}^{-1}\right)$ at a nitrate concentration of $560 \mathrm{mg} \mathrm{N}-\mathrm{NO}_{3}{ }^{-} 1^{-1}$. Although the reactor has revealed a very good performance in terms of denitrification, effluent chemical oxygen demand (COD) concentrations were still high for direct discharge. The results obtained in a subsequent experiment at constant nitrate concentration (220 mg N-NO${ }_{3}^{-} 1^{-1}$ ) and lower $\mathrm{C} / \mathrm{N}$ ratios (1.2 and 1.5) evidenced that the organic matter present in the leachate was non-biodegradable. A phosphorus concentration of $10 \mathrm{mg} \mathrm{P}-\mathrm{PO}_{4}{ }^{3-} 1^{-1}$ promoted autotrophic denitrification, revealing the importance of phosphorus concentration on biological denitrification processes.
\end{abstract}

Keywords Anoxic rotating biological contactor . $\mathrm{C} / \mathrm{N}$ ratio $\cdot$ Denitrification - Landfill leachate . Phosphorus

S. Cortez $\cdot$ P. Teixeira $\cdot$ R. Oliveira $(\bowtie) \cdot$ M. Mota IBB-Institute for Biotechnology and Bioengineering, Centre of Biological Engineering, University of Minho, Campus de Gualtar, 4710-057 Braga, Portugal

e-mail: roliveira@deb.uminho.pt

\section{Introduction}

The generation of leachate remains an inevitable consequence of the practice of waste disposal in sanitary landfills (Wang et al. 2010). Landfill leachate may contain a high concentration of organic matter such as volatile fatty acids, humic and fulvic compounds; inorganic contaminants such as ammonium, sulphate and chloride; heavy metals and xenobiotic organic substances (Wang et al. 2010; Xu et al. 2010).

The nitrogen compounds that exist in the landfill leachate can be removed by a variety of processes of which biological nitrogen removal has been widely adopted.

For instance, Chen et al. (2008) used a moving-bed biofilm reactor (MBBR) system with an anaerobic and aerobic arrangement for simultaneous removal of COD and ammonium from landfill leachate. As long as the hydraulic retention time (HRT) of the aerobic MBBR was more than 1.25 days, over $97 \%$ of the total $\mathrm{N}^{-\mathrm{NH}_{4}}{ }^{+}$removal efficiency could be achieved. Kulikowska et al. (2010) studied the nitrification of a landfill leachate in a rotating biological contactor (RBC) and at an ammonium load of $6.63 \mathrm{~g} \mathrm{~N}$ $\mathrm{NH}_{4}^{+} \mathrm{m}^{-2}$ day $^{-1}$ a nitrification efficiency of $71.6 \%$ was obtained. After pre-treatment of a landfill leachate, Hasar et al. (2009) applied an aerobic and anoxic membrane bioreactor and observed COD and total inorganic nitrogen (sum of nitrate, nitrite and ammonium) removals above 90 and $92 \%$, respectively, at a sludge retention time of 30 days. 
Leachates with high nitrogen-ammonium content may be difficult to treat by conventional biological treatment processes (Cema et al. 2007). Therefore, there has been a great need to improve existing technologies and to find new solutions concerning nitrogen removal. As an example, in the treatment of a landfill leachate, Cema et al. (2007) investigated an anaerobic ammonium oxidation (Anammox) process along with autotrophic nitrification and heterotrophic denitrification in one RBC and found that this system was able to completely remove the total inorganic nitrogen. Wang et al. (2010) and Xu et al. (2010) also applied systems with the integration of partial nitrification, Anammox and heterotrophic denitrification processes in sequencing batch reactors with very good performances in organic matter and nitrogen removal. Some drawbacks of these processes are that they might be very complex to operate and it may take months to achieve its full operation. New solutions should continue, therefore, to be developed.

In Portugal, in many cases, after withstanding a series of oxidation processes in the treatment plant at the sanitary landfill, the leachate still presents a high nitrate concentration.

Biofilm systems offer some advantages compared to the suspended growth systems, such as higher resistance to toxic agents and a lower sensitivity to low temperatures. They provide good removal efficiencies, even with effluents with the low 5-day biochemical oxygen demand $\left(\mathrm{BOD}_{5}\right)$ to chemical oxygen demand (COD) ratio $\left(\mathrm{BOD}_{5} / \mathrm{COD}\right)$ commonly found in many leachates (Gálvez et al. 2009). Biofilm technology has been shown to be an economic and effective method to degrade nitrate (Moreno et al. 2005). The availability and type of organic carbon compounds and the oxidation/reduction state of wastewater determine, to a large extent, the occurrence of nitrate reduction (van Rijn et al. 2006). Microbial growth and composition and microbiota type in the biofilm are also significant factors that affect the effluent quality and the application of a biofilm technology for water and wastewater treatment (Lazarova and Manem 1995). In turn, microbial growth is regulated by many factors, being the availability of phosphorus one of the most important (Teixeira and Oliveira 2000).

In this study, an anoxic RBC consisting of a series of closely spaced discs mounted on a common horizontal shaft, completely submerged in the leachate to be treated and inserted in a tightly closed case to avoid air entrance was used. This type of reactor was chosen because it is simple to operate with low operating and maintenance costs, high biomass concentration, high specific surface area, short hydraulic retention time (HRT) and relatively small accumulation of sloughed biofilm.

The aim of the present work was to evaluate the performance of an anoxic lab-scale RBC in terms of denitrification of a landfill leachate with high nitrate concentration. Accordingly, the effect of initial nitrate concentration on the reactor performance was assessed, as well as the effect of phosphorus concentration and $\mathrm{C} / \mathrm{N}$ ratio.

\section{Materials and methods}

Experimental lab-scale reactor

The single-stage anoxic RBC consisted of 8 polymethylmethacrylate (PMMA) discs mounted on a rotating shaft. The total surface area was equal to $0.218 \mathrm{~m}^{2}$ for 8 discs. The scheme of the experimental reactor is shown in Fig. 1 and its design characteristics are listed in Table 1. The discs were completely immersed. The anoxic RBC was covered and sealed and no special precaution was taken to maintain anoxic conditions. The temperature was kept at $28^{\circ} \mathrm{C}$ by means of a heating jacket. Substrate was fed by a peristaltic pump at a constant hydraulic retention time (HRT) of $10 \mathrm{~h}$ and a flow rate of $0.25 \mathrm{~h} \mathrm{~h}^{-1}$. The treated effluent was collected in a receiving tank. Flow through discs was parallel to the rotating shaft.

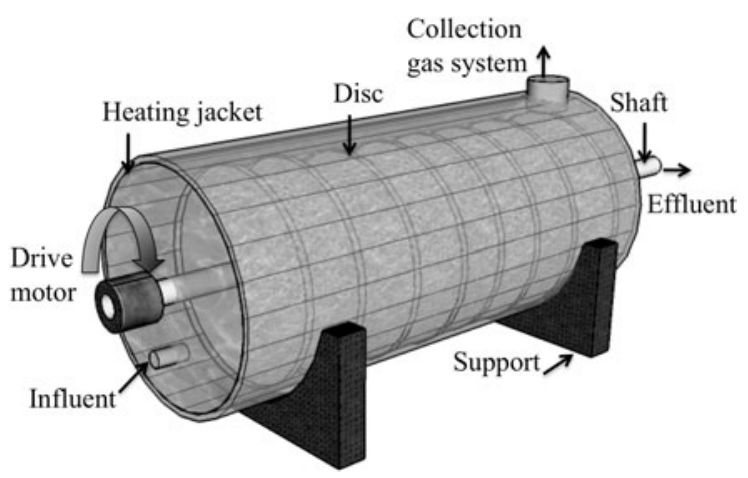

Fig. 1 Schematic representation of the anoxic lab-scale RBC and its design characteristics 
Table 1 Summary of the characteristics of the anoxic RBC experimental unit

\begin{tabular}{ll}
\hline Parameter & Value \\
\hline No. of stages & 1 \\
No. of discs/stage & 8 \\
Internal unit diameter $(\mathrm{mm})$ & 140 \\
Disc diameter $(\mathrm{mm})$ & 130 \\
Disc thickness $(\mathrm{mm})$ & 3 \\
Total surface area available for growth $\left(\mathrm{m}^{2}\right)$ & 0.218 \\
Disc spacing $(\mathrm{mm})$ & 20 \\
Shaft diameter $(\mathrm{mm})$ & 16 \\
Unit length $(\mathrm{mm})$ & 210 \\
Type of material & Acrylic \\
Rotational speed $(\mathrm{rpm})$ & 4 \\
Liquid volume $\left(\mathrm{dm}^{3}\right)$ & 2.5 \\
\hline
\end{tabular}

A Ritter MilliGascounter was used to measure the rate of produced gas.

Inoculum

A volume of concentrated biological sludge was collected from an activated sludge tank at Esposende Wastewater Treatment Plant, Portugal. In order to work with a suitable consortium, in the two experiments, the fresh biomass was acclimatised for 1 month in a denitrifying medium, under anoxic conditions, at room temperature, in conical flasks stirred at $150 \mathrm{rpm}$, using acetate as carbon source and a phosphorus concentration of $10 \mathrm{mg} \mathrm{P}-\mathrm{PO}_{4}{ }^{3-} \mathrm{1}^{-1}$. The denitrifying medium composition was 1134.0 or $850.6 \mathrm{mg} \mathrm{CH}_{3} \mathrm{COONa} \cdot 3 \mathrm{H}_{2} \mathrm{O} \mathrm{l}^{-1}$ according to the former or the latter experiment, respectively, $721.8 \mathrm{mg} \mathrm{KNO}_{3} \mathrm{l}^{-1}, 60.9 \mathrm{mg} \mathrm{K}_{2} \mathrm{HPO}_{4} \cdot 3 \mathrm{H}_{2} \mathrm{O} \mathrm{l}^{-1}$, $9.0 \mathrm{mg} \mathrm{K \textrm {K } _ { 2 }} \mathrm{PO}_{4} \mathrm{l}^{-1}$ and $100 \mathrm{ml}$ of trace elemental solution, which contained: $242 \mathrm{mg} \mathrm{Na} \mathrm{MoO}_{4} \cdot 2 \mathrm{H}_{2} \mathrm{O}$, $56 \mathrm{mg} \mathrm{FeSO}_{4} \cdot 7 \mathrm{H}_{2} \mathrm{O}, 8.1 \mathrm{mg} \mathrm{MnCl}_{2} \cdot 2 \mathrm{H}_{2} \mathrm{O}, 390 \mathrm{mg}$ $\mathrm{CaCl}_{2} \cdot 2 \mathrm{H}_{2} \mathrm{O}$ and $409.2 \mathrm{mg} \mathrm{MgSO}_{4} \cdot 7 \mathrm{H}_{2} \mathrm{O}$ per litre of tap water. Due to the medium buffering capacity, no $\mathrm{pH}$ adjustment was performed.

Landfill leachate characteristics

Landfill leachate was collected from a municipal landfill in the North of Portugal, in operation since 1998, after having been treated in the treatment plant existing in the sanitary landfill, which comprises
Table 2 Landfill leachate average characteristics

\begin{tabular}{lcc}
\hline Parameter & Experiment 1 & Experiment 2 \\
\hline $\mathrm{pH}$ & $5.72 \pm 0.03$ & $4.13 \pm 0.06$ \\
$\mathrm{COD}\left(\mathrm{mg} \mathrm{l}^{-1}\right)$ & $453 \pm 8$ & $866 \pm 16$ \\
$\mathrm{TOC}\left(\mathrm{mg} \mathrm{l}^{-1}\right)$ & $172 \pm 5$ & $366 \pm 8$ \\
$\mathrm{~N}^{-N^{-}}{ }^{-}\left(\mathrm{mg} \mathrm{l}^{-1}\right)$ & $1118 \pm 50$ & $1103 \pm 24$ \\
$\mathrm{~N}^{-N_{2}}{ }^{-}\left(\mathrm{mg} \mathrm{l}^{-1}\right)$ & $0.08 \pm 0.05$ & $0.19 \pm 0.06$ \\
$\mathrm{~N}_{-} \mathrm{NH}_{4}{ }^{+}\left(\mathrm{mg} \mathrm{l}^{-1}\right)$ & $197 \pm 7$ & $470 \pm 6$ \\
$\mathrm{P}_{-} \mathrm{PO}_{4}{ }^{3-}\left(\mathrm{mg} \mathrm{l}^{-1}\right)$ & $1.03 \pm 0.07$ & $1.50 \pm 0.53$ \\
\hline
\end{tabular}

stabilisation and anaerobic ponds, an anoxic tank, aerated ponds and a biological decantation unit, together with an oxidation tank and two chemical precipitators. The collected leachate was stored in closed containers at $4^{\circ} \mathrm{C}$ until use. The characteristics of the undiluted leachate used in the experiments are summarised in Table 2.

From Table 2 it can be seen that the major problem associated with the already treated leachate is its extremely high nitrogen-nitrate concentration.

Experimental procedure

The study consisted of two experiments. In both of them, for biofilm development, the lab-scale reactor was inoculated with acclimatised sludge and was operated in batch mode for 5 days. After that time, the anoxic RBC mixed liquor was removed, the reactor was re-filled with fresh substrate and started to operate in a continuous mode. The hydraulic retention time, very high at the beginning, was gradually reduced during 8 days. The time "zero" of operation was set 2 days after having the HRT stabilised at $10 \mathrm{~h}$, when samples started to be collected.

Throughout the study, considering the low carbon content of the leachate tested and since acetate is known to give the highest denitrification rates (Tam et al. 1992; Elefsiniotis and Wareham 2007), sodium acetate was added as supplementary carbon source. The amount of sodium acetate needed to attain the desired $\mathrm{C} / \mathrm{N}$ was calculated taking into account the total organic carbon present in the landfill leachate.

The first experiment-Experiment 1-was designed to evaluate the effect of initial nitrate concentration on reactor performance and lasted for 26 days. Nitrate influent concentration was gradually 
Table 3 Operating conditions of the anoxic RBC during the study of the effect of initial nitrate concentration on the reactor performance (Experiment 1)

\begin{tabular}{llll}
\hline $\begin{array}{l}\text { Days of } \\
\text { operation }\end{array}$ & Type of influent & $\mathrm{C} / \mathrm{N}$ & $\begin{array}{l}\mathrm{N}^{-\mathrm{NO}_{3}} \\
\left(\mathrm{mg} \mathrm{l}^{-1}\right)\end{array}$ \\
\hline $0-6$ & Synthetic wastewater & 2.0 & 100 \\
$6-13$ & Landfill leachate & & 140 \\
$13-20$ & & & 280 \\
$20-26$ & & 560 \\
\hline
\end{tabular}

Table 4 Operating conditions of the anoxic RBC during the study of the $\mathrm{C} / \mathrm{N}$ effect and phosphorus concentration on the reactor performance (Experiment 2)

\begin{tabular}{|c|c|c|c|c|}
\hline $\begin{array}{l}\text { Days of } \\
\text { operation }\end{array}$ & $\begin{array}{l}\text { Type of } \\
\text { influent }\end{array}$ & $\mathrm{C} / \mathrm{N}$ & $\begin{array}{l}\mathrm{N}^{-\mathrm{NO}_{3}}{ }^{-} \\
\left(\mathrm{mg} \mathrm{l}^{-1}\right)\end{array}$ & $\begin{array}{l}\mathrm{P}-\mathrm{PO}_{4}{ }^{3-} \\
\left(\mathrm{mg} \mathrm{l}^{-1}\right)\end{array}$ \\
\hline $0-13$ & Landfill leachate & 1.5 & 220 & 0.3 \\
\hline $13-20$ & & 1.2 & & 0.3 \\
\hline $20-27$ & & 1.2 & & 10 \\
\hline $27-36$ & & 1.5 & & 10 \\
\hline $36-42$ & & 2.0 & & 10 \\
\hline
\end{tabular}

increased (by reducing leachate dilution), while all other operating parameters were kept constant, as listed in Table 3. At the beginning of the experiment the reactor was fed with synthetic wastewater, having a composition similar to the denitrifying medium described below.

Another experiment-Experiment 2-followed Experiment 1 to evaluate the influence of carbon to nitrogen ratio $(\mathrm{C} / \mathrm{N})$ and phosphorus concentration on denitrification (Table 4). Experiment 2 was performed using a five-fold diluted landfill leachate and lasted for 42 days. The required phosphorus concentration was achieved adding to the influent a calculated amount of $\mathrm{KH}_{2} \mathrm{PO}_{4}$.

\section{Process monitoring}

During the course of operation, samples of the RBC influent and effluent were regularly collected and analysed for $\mathrm{pH}$, chemical oxygen demand (COD), nitrogen-nitrate $\left({\mathrm{N}-\mathrm{NO}_{3}}^{-}\right)$, nitrogen-nitrite $\left(\mathrm{N}^{-} \mathrm{NO}_{2}{ }^{-}\right)$, nitrogen-ammonium $\left(\mathrm{N}^{-} \mathrm{NH}_{4}{ }^{+}\right)$and carbon-acetate $\left(\mathrm{C}-\mathrm{CH}_{3} \mathrm{COO}^{-}\right) \cdot \mathrm{pH}$ values were immediately measured after the collection of the sample with a $\mathrm{pH}$ meter. COD, nitrogen-nitrite, and nitrogen-ammonium were determined according to the standard methods (APHA et al. 1989). Nitrate and acetate concentrations were measured by high-performance liquid chromatography (HPLC), using a Varian Metacarb column (type 67H, $9 \mu \mathrm{m}, 300 \mathrm{~mm}$ long, $6.5 \mathrm{~mm}$ internal diameter) and a mobile phase of $0.005 \mathrm{M}$ sulphuric acid $\left(\mathrm{H}_{2} \mathrm{SO}_{4}\right)$ at $0.7 \mathrm{ml} \mathrm{min}{ }^{-1}$. Column temperature was set at $60^{\circ} \mathrm{C}$ and nitrate and acetate were detected by UV at $210 \mathrm{~nm}$. Periodically, gas samples were analysed by a gas chromatograph (GC) equipped with a thermal conductivity detector and a Porapak Q column (2 $\mathrm{mm}$ internal diameter, 80-100 $\mu \mathrm{m}$ mesh, $1 \mathrm{~m}$ length) in series with a Molecular Sieve column (2 $\mathrm{mm}$ internal diameter, $5 \AA$, 80-100 $\mu \mathrm{m}$ mesh, 2 m length). Helium was used as the carrier gas at a flow rate of $17 \mathrm{ml} \mathrm{min}^{-1}$. Temperatures of the injector port, columns and detector were 110,35 and $110^{\circ} \mathrm{C}$, respectively. Total organic carbon (TOC) analyses were performed using a Dohrmann DC-190 total organic carbon analyser.

\section{Results and discussion}

\section{Effect of influent nitrate concentration}

The influence of initial nitrate concentration on denitrification efficiency was investigated by changing the nitrogen-nitrate concentration (from about 100 to $560 \mathrm{mg} \mathrm{N}-\mathrm{NO}_{3}{ }^{-} \mathrm{1}^{-1}$ ), keeping a $\mathrm{C} / \mathrm{N}$ ratio of 2. This ratio is slightly higher than the theoretical value of 1.4 obtained considering the approach of McCarty et al. (1969) when acetate is the carbon source, given by the stoichiometric equation:

$$
\begin{aligned}
\mathrm{NO}_{3}^{-} & +0.826 \mathrm{CH}_{3} \mathrm{COO}^{-}+1.816 \mathrm{H}^{+} \\
\rightarrow & 1.302 \mathrm{CO}_{2}+0.07 \mathrm{C}_{5} \mathrm{H}_{7} \mathrm{O}_{2} \mathrm{~N}+1.9 \mathrm{H}_{2} \mathrm{O} \\
& +0.467 \mathrm{~N}_{2}
\end{aligned}
$$

However, some carbon is used for the removal of oxygen from the system. Therefore, a conservative assumption was made to ensure complete denitrification during the experiment. Fine-tuning of carbon dosages were investigated in a later experiment.

Figure 2 shows the effect of influent nitrate-nitrogen concentration on nitrate removal and $\mathrm{N}_{-} \mathrm{NO}_{2}{ }^{-}$and $\mathrm{N}-\mathrm{NH}_{4}{ }^{+}$effluent concentrations. The reactor presented a very good performance in terms of nitrate removal when synthetic wastewater was used as influent. The change from synthetic wastewater to leachate and the slight increase in nitrate concentration (day 6) caused 
initially a decrease in nitrate removal efficiency to $75 \%$. This was certainly a transient response to the change of influent, corresponding to biofilm acclimatisation phase. Nitrate removal efficiency recovered fast and was kept around $99 \%$ as on day 10 . When the nitrate concentration was doubled on day 13 and again on day 20 , the nitrate reduction remained approximately constant.

Throughout the experiment, the actual amount of nitrate removed increased, which indicates that the denitrification rate increased with the initial nitrate concentration. This fact might be explained by the increase in electron acceptor when the nitrate concentration increased.

Excluding the biofilm adaptation periods, even for the greatest influent nitrate concentration tested, effluent $\mathrm{N}^{-\mathrm{NO}_{3}}{ }^{-}$concentration was less than or equal to $10 \mathrm{mg} \mathrm{l}^{-1}$, being below the established limit for discharge into fresh water $\left(10-30 \mathrm{mg} \mathrm{N}^{-\mathrm{NO}_{3}}{ }^{-} \mathrm{1}^{-1}\right.$ ) (European Comission 1991). Regarding the results achieved with landfill leachate, the denitrification rate increased from 13 to $55 \mathrm{mg} \quad \mathrm{N}_{-} \mathrm{NO}_{3}{ }^{-} \mathrm{l}^{-1} \mathrm{~h}^{-1}$ (4-15 ${\mathrm{g} \mathrm{N}-\mathrm{NO}_{3}}^{-} \mathrm{m}^{-2} \mathrm{~d}^{-1}$ ) when the initial nitrate increased from 140 to $560 \mathrm{mg} \mathrm{N}-\mathrm{NO}_{3}{ }^{-} \mathrm{1}^{-1}$ at $28^{\circ} \mathrm{C}$ with sodium acetate as carbon source. In a previous study, Calli et al. (2005) obtained denitrification rates in the range 33.3-120.8 $\mathrm{mg} \mathrm{N}-\mathrm{NO}_{\mathrm{x}}^{-} \mathrm{l}^{-1} \mathrm{~h}^{-1}\left(\mathrm{~N}_{-} \mathrm{NO}_{\mathrm{x}}{ }^{-}\right.$ nitrogen from nitrate and nitrite compounds) in the treatment of a young landfill leachate at room temperature (from 17 to $26^{\circ} \mathrm{C}$ ) with sodium acetate as carbon source. A denitrification rate of $55 \mathrm{mg}$ $\mathrm{N}-\mathrm{NO}_{3}{ }^{-} \mathrm{l}^{-1} \mathrm{~h}^{-1}$ was achieved by Welander et al. (1998) in a suspended carrier biofilm reactor, treating mature leachate at $17^{\circ} \mathrm{C}$ but using methanol as external carbon source. The denitrification rates obtained in the present work are similar to the values reported in the literature. However, it is difficult to make comparisons due to differences in temperature, $\mathrm{pH}$, initial $\mathrm{N}_{-} \mathrm{NO}_{3}{ }^{-}$and $\mathrm{N}-\mathrm{NO}_{2}{ }^{-}$concentrations, carbon sources used, $\mathrm{C} / \mathrm{N}$ ratio, hydraulic retention times and phosphorus content, parameters that are also determinant in the nitrate removal process.

The selected retention time of $10 \mathrm{~h}$ was adequate to assure the nitrate removal performance. Also, the obtained results demonstrate the viability of the anoxic RBC in the denitrification of a pre-treated landfill leachate.

Nitrite accumulation during denitrification of landfill leachates has been observed in many studies
(Chen et al. 2009; Martienssen and Schops 1997; Sun et al. 2009). However, it is very important to avoid nitrite accumulation because it can lead to inhibition of bacterial development (Martienssen and Schops 1997). Moreover, high nitrite content is highly undesirable as nitrite is more toxic than nitrate (Welander et al. 1998). It can be seen from Fig. 2b that effluent $\mathrm{N}_{-} \mathrm{NO}_{2}{ }^{-}$was around $3 \mathrm{mg} \mathrm{l}^{-1}$ when the influent was synthetic wastewater. By changing the influent to leachate, an increase in nitrogen-nitrite accumulation was noted followed by a rapid and significant drop. A plausible explanation for this behaviour may be related with the activity of the enzyme nitrite reductase present in the microbial biofilm community, which is only stimulated when a considerable nitrite concentration is produced. Another possible explanation for this phenomenon
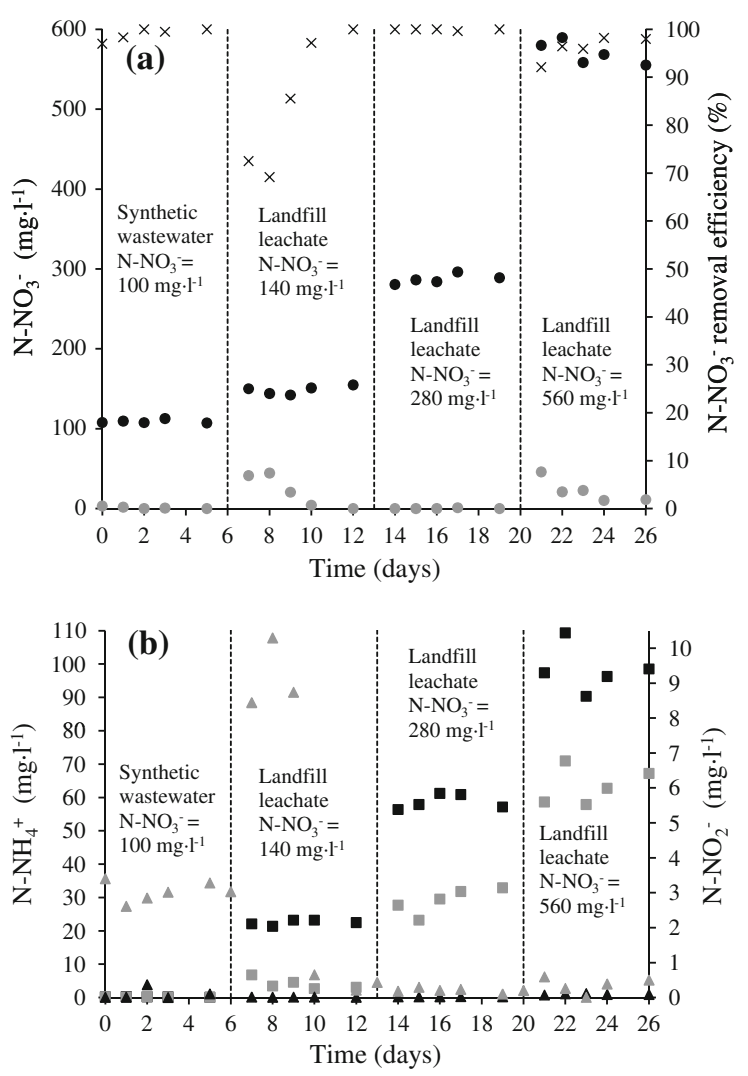

Fig. 2 Effect of influent nitrate concentration on nitrogenous compounds. a Influent (filled black circle) and effluent (filled grey circle) $\mathrm{N}_{-} \mathrm{NO}_{3}{ }^{-}$concentration and $\mathrm{N}^{-} \mathrm{NO}_{3}{ }^{-}$removal efficiency (times); b Influent (filled black square) and effluent (filled grey square) $\mathrm{N}^{-\mathrm{NH}_{4}}{ }^{+}$concentration, influent (filled black triangle) and effluent (filled grey triangle) $\mathrm{N}_{-} \mathrm{NO}_{2}{ }^{-}$ concentration 
is the sudden increase of ammonium in the reactor, which might have inhibited temporarily the growth of nitrite oxidising bacteria, although followed by a rapid recovery (Terada et al. 2003). The increase in nitrate concentration had no significant influence in nitrite effluent concentration.

Ammonium is also an undesirable compound since it can be toxic to aquatic microorganisms. As illustrated in Fig. 2b a significant ammonium removal was observed when landfill leachate was fed to the reactor. This is probably due to ammonium reduction by nitrite to form gaseous nitrogen. In fact, in the beginning there was some nitrite accumulation and a low ammonium reduction but when the ammonium reduction rises to about $50 \%$ nitrite accumulation is almost negligible.

The changes in $\mathrm{COD}$ and $\mathrm{C}-\mathrm{CH}_{3} \mathrm{COO}^{-}$concentrations throughout the experiment are shown in Fig. $3 a$ and $b$, respectively. Until the sixth day of
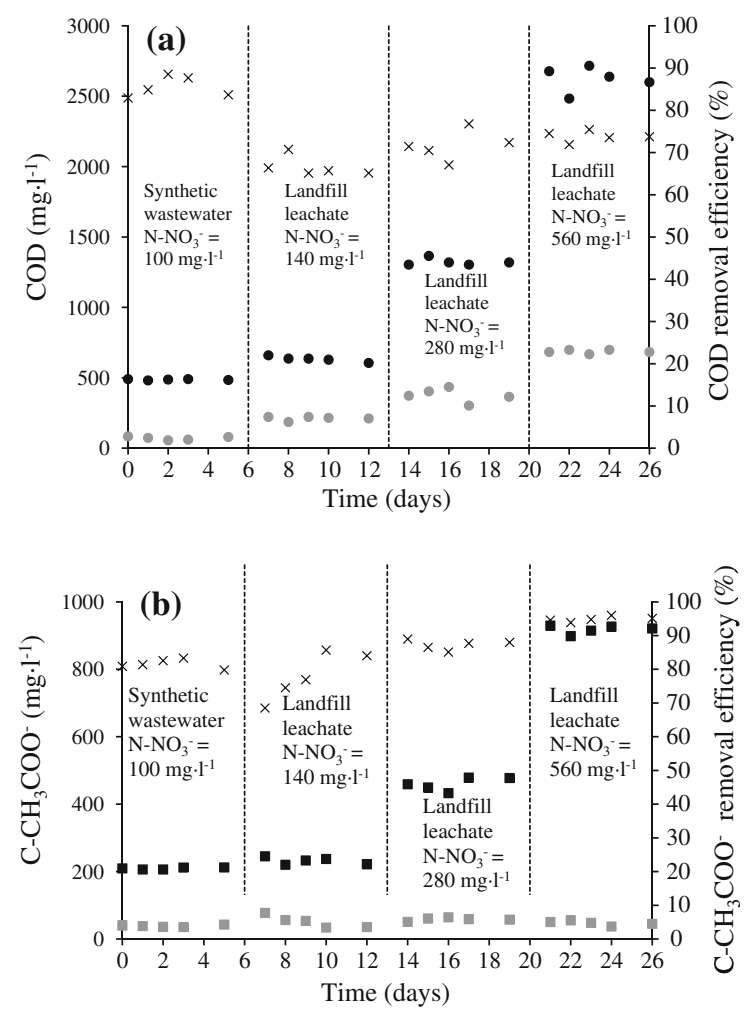

Fig. 3 Effect of influent nitrate concentration on carbonaceous compounds. a Influent (filled black circle) and effluent (filled grey circle) COD concentration and COD removal efficiency (times); b Influent (filled black square) and effluent (filled grey square) $\mathrm{C}-\mathrm{CH}_{3} \mathrm{COO}^{-}$concentration and $\mathrm{C}-\mathrm{CH}_{3} \mathrm{COO}^{-}$removal efficiency (times) operation COD influent values were only due to the addition of acetate. From day 6 onwards, these data correspond to the contribution of added acetate and carbon content from the landfill leachate.

During the first experimental period, around 82\% of carbon-acetate was consumed and showed to be enough to assure $99 \%$ of nitrogen-nitrate removal. This implies that the reactor was not carbon limited and was receiving enough carbon to promote the denitrification process. Effluent COD concentration was approximately $71 \mathrm{mg} \mathrm{l}^{-1}$. After the shift to leachate and the corresponding biofilm acclimatisation phase, small variations in COD removal values were observed until the end of the experiment. The carbon-acetate removal efficiency slightly increased with the increasing nitrate concentration. This trend may be due to the lower amount of acetate fed to the reactor when leachate was used as influent, thereby remaining less acetate in the effluent. The carbon content of the leachate is most probably less degradable than acetate, which might also explain the observed differences. The effluent COD concentrations reached values greater than $125 \mathrm{mg}^{-1}$, which is the discharge standard value. Therefore, in order to fulfil environmental regulations, for high nitrate loads, the acetate concentration should be adjusted and biodegradability studies concerning the landfill leachate must be carried out.

$\mathrm{pH}$ values increased from 6.4-7.3 in the influent to 7.8-9.4 in the effluent. The observed $\mathrm{pH}$ trend might be attributed to the conversion of $\mathrm{N}_{-} \mathrm{NO}_{3}{ }^{-}$to nitrogen gas in the reactor, which consumed hydrogen ions. This effect was more relevant as the inlet nitrate concentration increased. The optimum $\mathrm{pH}$ for most environmental strains of denitrifying bacteria was reported between 7.0 and 8.0 (Tchobanoglous and Burton 1991). In the present study high nitrate removals were even possible for $\mathrm{pH}$ above 9.0, which leads to the conclusion that the increased $\mathrm{pH}$ was not inhibitory.

The produced gas flow rate, as expected, increased with the increasing nitrate concentration, in agreement with the nitrogen-nitrate removal efficiency profile (Fig. 4a).

Gas composition was measured at NTP conditions as a percentage by volume and data are shown in Fig. 4b. The gas composition remained almost unchanged with the increasing nitrate concentration. Nitrogen $\left(\mathrm{N}_{2}\right)$ was the main compound in the analysed gas composition (around 90\%). Release of 

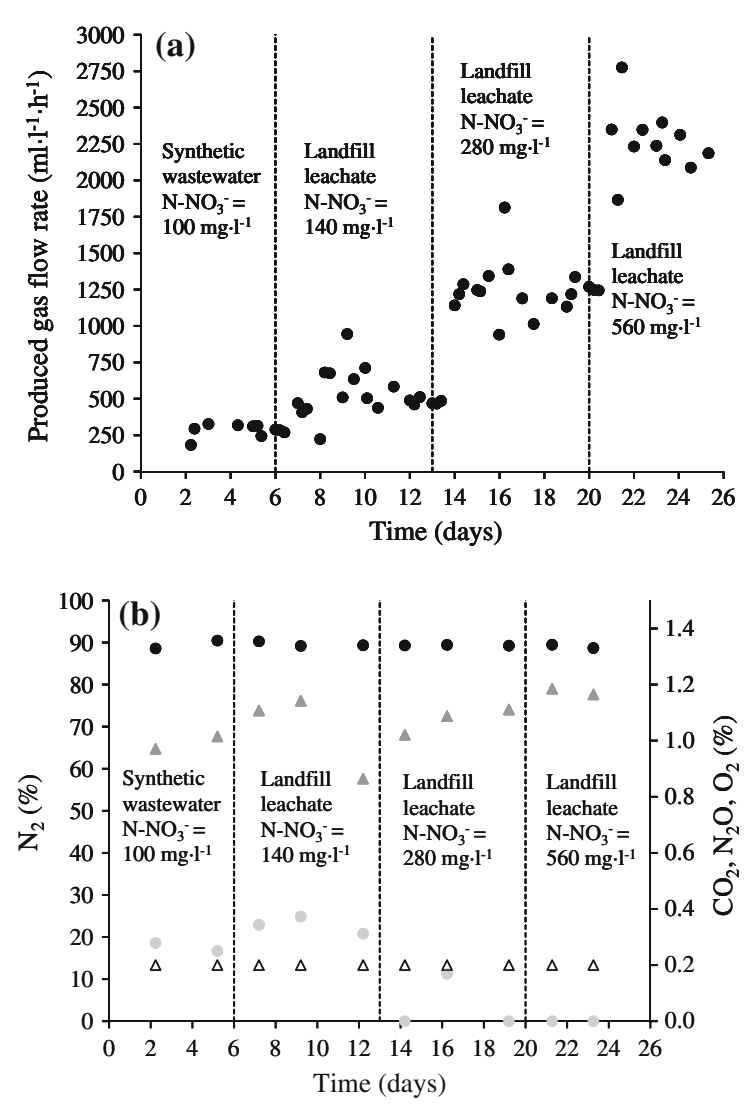

Fig. 4 Effect of influent nitrate concentration on a produced gas flow rate; $\mathbf{b}$ produced gas composition: $\mathrm{N}_{2}$ (filled black circle); $\mathrm{CO}_{2}$ (filled grey triangle); $\mathrm{N}_{2} \mathrm{O}$ (triangle) and $\mathrm{O}_{2}$ (filled grey circle)

$\mathrm{CO}_{2}$ was low because it was mainly solubilised in the medium, promoting an increase in alkalinity. Production of $\mathrm{N}_{2} \mathrm{O}$ was below $0.2 \%$ (minimum detection value). A small concentration of $\mathrm{O}_{2}$ (approximately $0.3 \%$ ) was detected in the gas composition analysed until day 13. It is important to note that biological denitrification was considered before to be strictly anoxic (Payne 1973). However, the present results confirm that, as reported by (Lukow and Diekmann 1997), with a certain number of bacteria, denitrification occurs in the presence of $\mathrm{O}_{2}$. No methane or hydrogen sulfide gases were detected by the measuring system.

During this experiment, the anoxic RBC presented a very good denitrification performance. Almost all nitrate was reduced to nitrogen gas and no nitrite accumulation was found. The biofilm attached to the discs was slightly sensitive to variations in substrate, which is a desirable characteristic when landfill leachate with such high nitrogen-nitrate content is being treated. The main drawback of the system was the unused carbon remaining in the treated effluent with increased COD discharge. Therefore, an efficient acetate dosage strategy is required, which was considered in the following experiment (Experiment 2).

Effect of $\mathrm{C} / \mathrm{N}$ ratio and influent phosphorus concentration

Dosage of external carbon source is a tricky parameter to control in a denitrification process. A poor $\mathrm{C} / \mathrm{N}$ ratio leads to incomplete denitrification resulting in a significant increase in the effluent nitrate concentration or accumulation of intermediate products, such as $\mathrm{NO}_{2}$ and $\mathrm{N}_{2} \mathrm{O}$. On the other hand a high $\mathrm{C} / \mathrm{N}$ ratio is an extra cost and may promote dissimilatory nitrate reduction to ammonia and the presence of carbon in the denitrified effluent (Her and Huang 1995). Therefore, the $\mathrm{C} / \mathrm{N}$ ratio must be properly controlled.

The nature and concentration of influent substrates may affect biofilm growth and composition. Under a high substrate loading rate, the biofilm accumulation is higher. The limitation in some nutrients, as phosphorus, may enhance polysaccharide production instead of cell formation in the biofilm and consequently the concentration of active biomass (Veiga et al. 1992).

The influence of $\mathrm{C} / \mathrm{N}$ on denitrification efficiency was investigated by changing the carbon concentration, keeping constant the nitrate concentration (220 $\mathrm{mg} \mathrm{N}-\mathrm{NO}_{3}{ }^{-} 1^{-1}$ ). A range of $\mathrm{C} / \mathrm{N}$ between 1.45 and 2 is reported in the literature (MohseniBandpi et al. 1999; Reyes-Avila et al. 2004) for denitrification using acetate as carbon source. Based on the data from the previous trial, this experiment started with a $\mathrm{C} / \mathrm{N}$ ratio almost identical to the ratio given by the stoichiometric equation: 1.5 .

It can be seen in Fig. 5 that, under the running conditions of $\mathrm{C} / \mathrm{N}=1.5$ and $0.3 \mathrm{mg} \mathrm{P}-\mathrm{PO}_{4}{ }^{3-} \mathrm{l}^{-1}$, the nitrogen-nitrate removal efficiency was around $63 \%$. Considering the concentration of $\mathrm{N}^{-\mathrm{NO}_{3}}{ }^{-}$in the effluent, this removal was relatively low, however some acetate still remained in the treated leachate (Fig. 6), showing that the reactor was not carbon limited. After 13 days of operation, the $\mathrm{C} / \mathrm{N}$ ratio was adjusted from 1.5 to 1.2 , which is below the theoretical value. The aim of this change in the $\mathrm{C} / \mathrm{N}$ ratio was to reduce the concentration of $\mathrm{COD}$ in the 

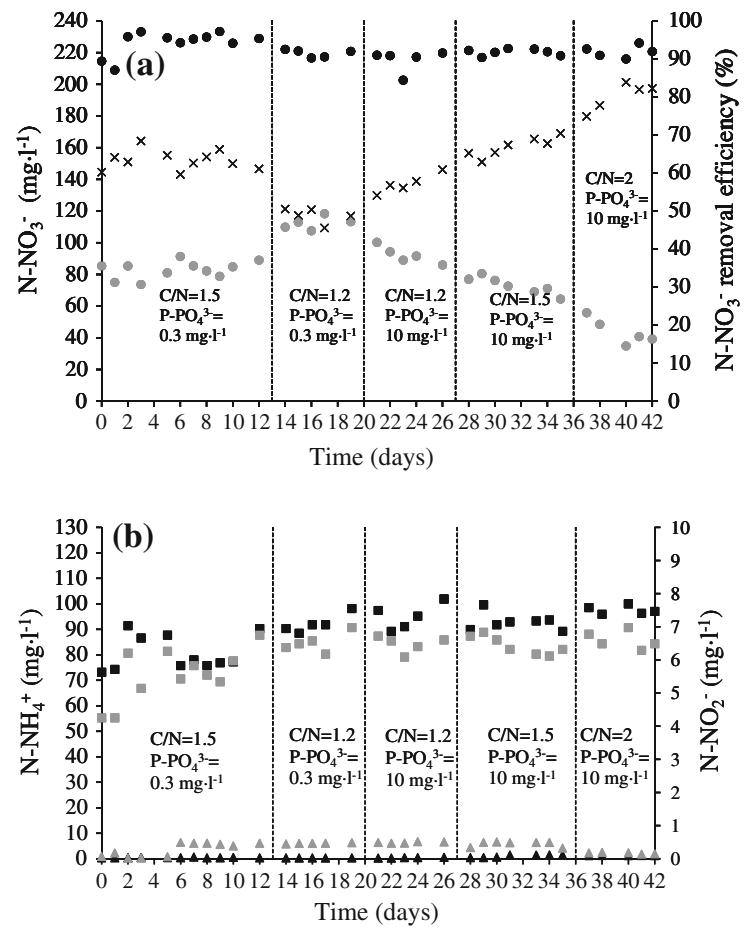

Fig. 5 Effect of $\mathrm{C} / \mathrm{N}$ ratio and phosphorus concentration on nitrogenous compounds. a Influent (filled black circle) and effluent (filled grey circle) $\mathrm{N}_{-} \mathrm{NO}_{3}{ }^{-}$concentration and $\mathrm{N}-\mathrm{NO}_{3}{ }^{-}$ removal efficiency (times); b Influent (filled black square) and effluent (filled grey square) $\mathrm{N}_{-} \mathrm{NH}_{4}{ }^{+}$concentration, influent (filled black triangle) and effluent (filled grey triangle) $\mathrm{N}$ $\mathrm{NO}_{2}{ }^{-}$concentration

effluent and to examine into what extent the organic matter in the leachate could be used as carbon source for the denitrification process. As a consequence, acetate was completely consumed and effluent COD concentration remained near the reference value of $125 \mathrm{mg} \mathrm{l}^{-1}$ but $\mathrm{N}^{-\mathrm{NO}_{3}}{ }^{-}$removal efficiency decreased to $48 \%$. Since all acetate was consumed and effluent COD was not, these results suggest that the organic matter present in the leachate should be non-biodegradable and the denitrifying biofilm could not use it. The $\mathrm{C} / \mathrm{N}$ of 1.2 , composed of carbon from sodium acetate and landfill leachate, was insufficient for the denitrification process.

Considering that influent phosphorus concentration can significantly affect the denitrifying process (Alves et al. 2002; Teixeira and Oliveira 2000), in an attempt to make the microbial community consume the leachate organic matter, $\mathrm{P}_{-} \mathrm{PO}_{4}{ }^{3-}$ influent concentration was changed to $10 \mathrm{mg} \mathrm{l}^{-1}$, from day 20 onwards. Phosphorus concentration was selected according to
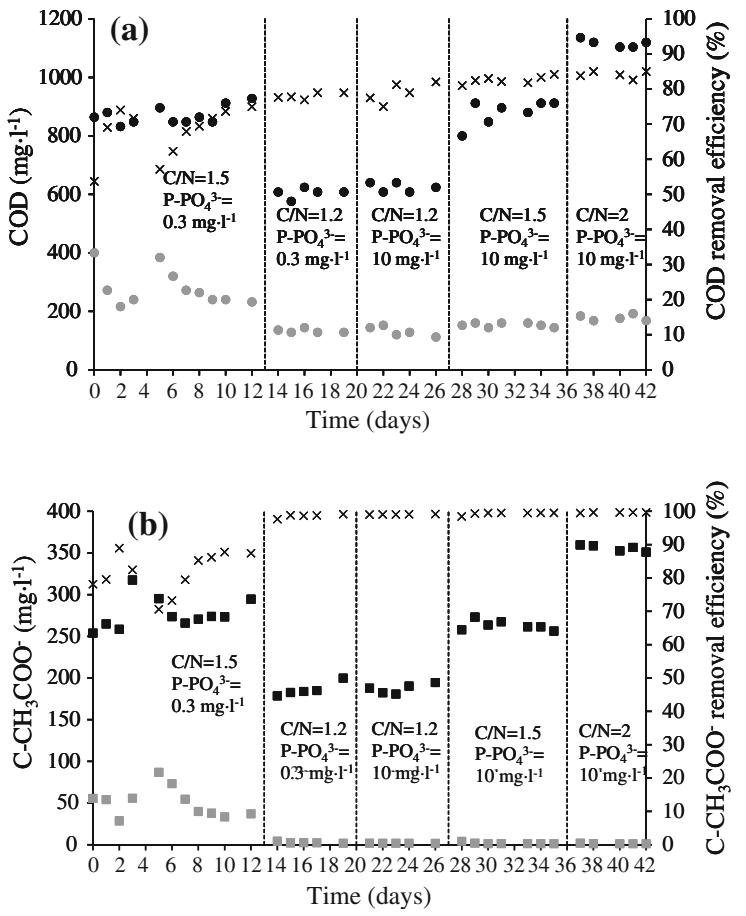

Fig. 6 Effect of $\mathrm{C} / \mathrm{N}$ ratio and phosphorus concentration on carbonaceous compounds. a Influent (filled black circle) and effluent (filled grey circle) COD concentration and COD removal efficiency (times); b Influent (filled black square) and effluent (filled grey square) $\mathrm{C}_{-} \mathrm{CH}_{3} \mathrm{COO}^{-}$concentration and $\mathrm{C}$ $\mathrm{CH}_{3} \mathrm{COO}^{-}$removal efficiency (times)

Welander et al. (1998). The shift to a higher phosphorus concentration, keeping $\mathrm{C} / \mathrm{N}=1.2$, led to a moderately increase in nitrogen-nitrate removal efficiency, while no effect was detected on COD removal efficiency. A possible explanation might be that a high phosphorus concentration led to the growth of autotrophic denitrifying microorganisms. A higher activity of autotrophic denitrifying microorganisms usually occurs in environments with low $\mathrm{C} / \mathrm{N}$ ratios (Kim and Son 2000). Koenig and Liu (1996) showed that a decrease in the nitrate concentration was coupled with an increase in the sulphate concentration due to autotrophic denitrification.

Taking into account the positive effect of phosphorus concentration on nitrate removal, the high effluent $\mathrm{N}^{-\mathrm{NO}_{3}}{ }^{-}$concentration and the poor biodegradability of the landfill leachate, the $\mathrm{C} / \mathrm{N}$ ratio was increased again to 1.5 on day 27 and finally to 2 on day 36 keeping on working with $10 \mathrm{mg} \mathrm{P}-\mathrm{PO}_{4}{ }^{3-} \mathrm{1}^{-1}$. Nitrogen-nitrate removal efficiency notably increased, while small differences in COD and carbon-acetate 
removal values were noted under those conditions. High $\mathrm{C} / \mathrm{N}$ ratios with $10 \mathrm{mg} \mathrm{P}_{-} \mathrm{PO}_{4}{ }^{3-} 1^{-1}$ may have stimulated the growth of autotrophic and heterotrophic denitrifying bacteria in the biofilm and thus promoting a higher nitrate removal rate. The $\mathrm{C} / \mathrm{N}$ ratio required for complete denitrification, besides the nature of the carbon source, depends on the nature of the bacterial species (van Rijn et al. 2006).

The results suggest that for a nitrate concentration of $220 \mathrm{mg} \mathrm{N}-\mathrm{NO}_{3}{ }^{-} 1^{-1}$, a better reactor performance was achieved with $\mathrm{C} / \mathrm{N}=2$ and $10 \mathrm{mg} \mathrm{P}-\mathrm{PO}_{4}{ }^{3-} 1^{-1}$. At these conditions, the highest denitrification rate was $18.5 \mathrm{mg} \mathrm{N}-\mathrm{NO}_{3}{ }^{-} \mathrm{l}^{-1} \mathrm{~h}^{-1}$.

Probably a further increase of the $\mathrm{C} / \mathrm{N}$ ratio would have allowed the complete removal of nitrate, as observed by Alves et al. (2002). In addition, it may be possible to optimise the phosphorus concentration in the range $0.3-10 \mathrm{mg} \mathrm{P}-\mathrm{PO}_{4}{ }^{3-} \mathrm{l}^{-1}$.

Nitrite accumulation was not observed, even when the $\mathrm{C} / \mathrm{N}$ ratio was lower than the stoichiometric value. The effluent ammonium concentrations were always lower than the input values.

$\mathrm{pH}$ values increased from 6.4-7.1 in the influent to 8.6-9.4 in the effluent.

The produced gas flow rate varied following the profile of nitrogen-nitrate removal efficiency (Fig. 7a).

The reactor was operated with approximately $0.4 \%$ of $\mathrm{O}_{2}$ (Fig. 7b). $\mathrm{CO}_{2}$ production remained around $1 \%$. Gas was mainly composed of $\mathrm{N}_{2} \cdot \mathrm{N}_{2} \mathrm{O}$ accumulation was observed when $\mathrm{C} / \mathrm{N}$ ratio was 1.2 . Hong et al. (1993) reported that a low $\mathrm{C} / \mathrm{N}$ ratio could result in $\mathrm{N}_{2} \mathrm{O}$ production. $\mathrm{N}_{2} \mathrm{O}$ is a potent greenhouse gas with high ozone depletion potential, therefore, it is important to minimise its emission.

The results obtained in this experiment showed that a limited $\mathrm{C} / \mathrm{N}$ ratio (less than the theoretical 1.4) resulted in an increase of effluent nitrate concentration and $\mathrm{N}_{2} \mathrm{O}$ production. The landfill leachate used was non-biodegradable, rich in refractory compounds and the denitrifying biofilm could not use its carbon content. Probably, to meet the maximum allowable organic matter concentration for discharge, advanced oxidation processes, such as ozone or Fenton oxidation should be applied before biological treatment.

The shift to a higher concentration of phosphorus seemed to favour the activity of autotrophic denitrifiers and therefore, nitrate removal. This result emphasises the importance of phosphorus
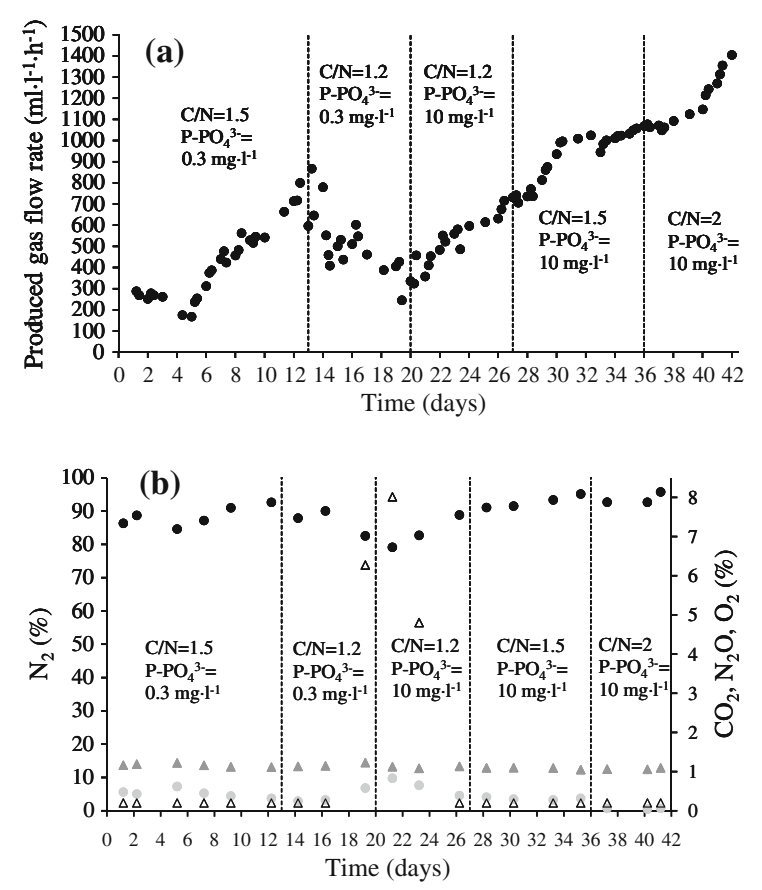

Fig. 7 Effect of $\mathrm{C} / \mathrm{N}$ ratio and phosphorus concentration on a produced gas flow rate; b produced gas composition: $\mathrm{N}_{2}$ (filled black circle); $\mathrm{CO}_{2}$ (filled grey triangle); $\mathrm{N}_{2} \mathrm{O}$ (triangle) and $\mathrm{O}_{2}$ (filled grey circle)

concentration as well as the composition of the biofilm community on the denitrification process. Better denitrification conditions were achieved with $\mathrm{C} / \mathrm{N}=2$ and $10 \mathrm{mg} \mathrm{P}_{-} \mathrm{PO}_{4}{ }^{3-} \mathrm{l}^{-1}$. Considering the nitrate concentration applied $\left(220 \mathrm{mg} \mathrm{N}-\mathrm{NO}_{3}{ }^{-} \mathrm{l}^{-1}\right)$ and since no nitrite accumulation was detected, the anoxic RBC showed an efficient performance in terms of denitrification.

\section{Conclusions}

Considering the nitrate concentration applied, nitrate removal efficiencies and the negligible accumulation of intermediates in both experiments, the anoxic rotating biological contactor showed to be very efficient and is a promising technology for removing nitrate from landfill leachate.

In order to improve leachate biological treatability, future research should focus on the removal and change of the recalcitrant organic matter by an advanced oxidation process, which must be applied before the biofilm reactor. Considering the ammonium 
content of the treated leachate, a system involving denitrification and nitrification followed by recirculation to the first unit should also be evaluated.

Acknowledgments Susana Cortez and Pilar Teixeira are grateful to Fundação para a Ciência e Tecnologia (FCT) for financial support through the grants SFRH/BD/24715/2005 and SFRH/BPD/26803/2006, respectively.

\section{References}

Alves C, Melo L, Vieira M (2002) Influence of medium composition on the characteristics of a denitrifying biofilm formed by Alcaligenes denitrificans in a fluidised bed reactor. Process Biochem 37:837-845. doi:10.1016/ S0032-9592(01)00282-5

APHA, AWWA, WPCF (1989) Standard methods for the examination of water and wastewater, American Public Health Association, American Water Works Association, 17th edn. Water Pollution Control Federation, Washington, DC

Calli B, Mertoglu B, Inanc B (2005) Landfill leachate management in Istanbul: applications and alternatives. Chemosphere 59:819-829. doi:10.1016/j.chemosphere.2004.10.064

Cema G, Wiszniowski J, Zabczynski S, Zablocka-Godlewska E, Raszka A, Surmacz-Gorska J (2007) Biological nitrogen removal from landfill leachate by deammonification assisted by heterotrophic denitrification in a rotating biological contactor (RBC). Water Sci Technol 55:35-42. doi:10.2166/wst.2007.239

Chen S, Sun D, Chung J (2008) Simultaneous removal of COD and ammonium from landfill leachate using an anaerobicaerobic moving-bed biofilm reactor system. Waste Manage 28:339-346. doi:10.1016/j.wasman.2007.01.004

Chen Y, Wu S, Wu W, Sun H, Ding Y (2009) Denitrification capacity of bioreactors filled with refuse at different landfill ages. J Hazard Mater 172:159-165. doi:10.1016/ j.jhazmat.2009.06.150

Comission European (1991) European Council Directive 91/ 271/EEC of 21 May 1991 on urban waste water treatment. Off J Eur Commun L 135:40-52

Elefsiniotis P, Wareham D (2007) Utilization patterns of volatile fatty acids in the denitrification reaction. Enzyme Microb Technol 41:92-97. doi:10.1016/j.enzmictec.2006.12.006

Gálvez A, Giusti L, Zamorano M, Ramos-Ridao A (2009) Stability and efficiency of biofilms for landfill leachate treatment. Bioresour Technol 100:4895-4898. doi:10.1016/ j.biortech.2009.05.014

Hasar H, Unsal SA, Ipek U, Karatas S, Cinar O, Yaman C, Kinaci C (2009) Stripping/flocculation/membrane bioreactor/reverse osmosis treatment of municipal landfill leachate. J Hazard Mater 171:309-317. doi:10.1016/ j.jhazmat.2009.06.003

Her JJ, Huang JS (1995) Influences of carbon source and $\mathrm{C} / \mathrm{N}$ ratio on nitrate/nitrite denitrification and carbon breakthrough. Bioresour Technol 54:45-51. doi:10.1016/ 0960-8524(95)00113-1
Hong K, Hu LF, Shen DS (1993) Greenhouse gas $-\mathrm{N}_{2} \mathrm{O}$ production during denitrification in wastewater treatment. Water Sci Technol 28:203-207

Kim I, Son J (2000) Impact of COD/N/S ratio on denitrification by the mixed cultures of sulfate reducing bacteria and sulfur denitrifying bacteria. Water Sci Technol 42:69-76

Koenig A, Liu LH (1996) Autotrophic denitrification of landfill leachate using elemental sulphur. Water Sci Technol 34:469-476. doi:10.1016/0273-1223(96)00680-4

Kulikowska D, Józwiak T, Kowal P, Ciesielski S (2010) Municipal landfill leachate nitrification in RBC biofilmprocess efficiency and molecular analysis of microbial structure. Bioresour Technol 101:3400-3405. doi:10.1016/ j.biortech.2009.12.050

Lazarova V, Manem J (1995) Biofilm characterization and activity analysis in water and wastewater treatment. Water Res 29:2227-2245. doi:10.1016/0043-1354(95)00054-O

Lukow T, Diekmann H (1997) Aerobic denitrification by a newly isolated heterotrophic bacterium strain TL1. Biotechnol Lett 19:1157-1159. doi:10.1023/A:1018465232392

Martienssen M, Schops R (1997) Biological treatment of leachate from solid waste landfill sites-alterations in the bacterial community during the denitrification process. Water Res 31:1164-1170. doi:10.1016/S0043-1354(96) 00364-8

McCarty P, Beck L, Amant P (1969) Biological denitrification of wastewaters by addition of organic materials. In: Purdue University (ed) Proceedings of the 24th Purdue Industrial Waste Conference Indiana, USA, pp 1271-1285

Mohseni-Bandpi A, Elliott D, Momeny-Mazdeh A (1999) Denitrification of groundwater using acetic acid as a carbon source. Water Sci Technol 40:53-59. doi:10.1016/ S0273-1223(99)00430-8

Moreno B, Gomez M, Gonzalez-Lopez J, Hontoria E (2005) Inoculation of a submerged filter for biological denitrification of nitrate polluted groundwater: a comparative study. J Hazard Mater 117:141-147. doi:10.1016/j.jhazmat.2004. 09.027

Payne W (1973) Reduction of nitrogenous oxides by microorganisms. Bacteriol Rev 37:409-452

Reyes-Avila J, Razo-Flores E, Gomez J (2004) Simultaneous biological removal of nitrogen, carbon and sulfur by denitrification. Water Res 38:3313-3321. doi:10.1016/ j.watres.2004.04.035

Sun H, Yang Q, Peng Y, Shi X, Wang S, Zhang S (2009) Nitrite accumulation during the denitrification process in SBR for the treatment of pre-treated landfill leachate. Chin J Chem Eng 17:1027-1031. doi:10.1016/S10049541(08)60312-2

Tam N, Wong Y, Leung G (1992) Effect of exogenous carbon sources on removal of inorganic nutrient by the nitrification-denitrification process. Water Res 26:1229-1236. doi:10.1016/0043-1354(92)90183-5

Tchobanoglous G, Burton F (1991) Wastewater engineering: treatment, disposal and reuse, 3rd edn. Metcalf and Eddy, Inc, McGraw-Hill Inc, New York

Teixeira P, Oliveira R (2000) Denitrification by Alcaligenes denitrificans in a closed rotating biological contactor. Biotechnol Lett 22:1789-1792. doi:10.1023/A:1005606421379

Terada A, Hibiya K, Nagai J, Tsuneda S, Hirata A (2003) Nitrogen removal characteristics and biofilm analysis of a 
membrane-aerated biofilm reactor applicable to highstrength nitrogenous wastewater treatment. J Biosci Bioeng 95:170-178. doi:10.1016/S1389-1723(03)80124-X

van Rijn J, Tal Y, Schreier HJ (2006) Denitrification in recirculating systems: theory and applications. Aquacult Eng 34:364-376. doi:10.1016/j.aquaeng.2005.04.004

Veiga MC, Mendez R, Lema JM (1992) Development and stability of biofilms in bioreactors. In: Melo LF, Bott TR, Fletcher M, Capdeville B (eds) Biofilms-science and technology. Kluwer Academic Publishers, Netherlands, pp 421-434

Wang C, Lee P, Kumar M, Huang Y, Sung S, Lin J (2010) Simultaneous partial nitrification, anaerobic ammonium oxidation and denitrification (SNAD) in a full-scale landfill-leachate treatment plant. J Hazard Mater 175:622-628. doi:10.1016/j.jhazmat.2009.10.052

Welander U, Henrysson T, Welander T (1998) Biological nitrogen removal from municipal landfill leachate in a pilot scale suspended carrier biofilm process. Water Res 32:1564-1570. doi:10.1016/S0043-1354(97)00351-5

Xu Z, Zeng G, Yang Z, Xiao Y, Cao M, Sun H, Ji L, Chen Y (2010) Biological treatment of landfill leachate with the integration of partial nitrification, anaerobic ammonium oxidation and heterotrophic denitrification. Bioresour Technol 101:79-86. doi:10.1016/j.biortech.2009.07.082 